\title{
Reforming Slovak Tertiary Education to Meet the Real Needs of Enterprises
}

\author{
Ing. L’ubomír Šooš* , Bc. Malcolm Jones \\ Faculty of Mechanical Engineering, STU, Bratislava \\ *Corresponding author: lubomir.soos@stuba.sk
}

Received August 29, 2014; Revised January 06, 2015; Accepted March 05, 2015

\begin{abstract}
Research, science, education, links with work experience, these are terms and words which everybody uses today when talking about what should be the main priority of education in the future for Slovakia. Education is the responsibility of each society or state. In this sense of the meaning we can never be rich enough. So we should ensure we invest our resources effectively in educating young people and investing in the future of our nation.
\end{abstract}

Keywords: science, education, work experience, Slovakia

Cite This Article: Ing. L'ubomír Šooš, and Bc. Malcolm Jones, "Reforming Slovak Tertiary Education to Meet the Real Needs of Enterprises.” American Journal of Educational Research, vol. 3, no. 3 (2015): $348-355$. doi: 10.12691/education-3-3-14.

\section{Introduction}

The state has responsibility for maximising the effectiveness of its financial investment in education in order to train modern and educated graduates for the practical needs of industry, business, and the requirements of running a modern state. It must also ensure that the results of the research undertaken in our educational establishments are appropriate to the needs of enterprises operating within the national territory and beyond. Furthermore it should also ensure that the education system develops the intellectual products with the highest added value, i.e. progressive and innovative ones, which will have the greatest potential for being disseminated.

Unfortunately, financial resources are currently being allocated ineffectively by the Slovak state, three times over. Firstly, money from the Ministry of Education is given to schools which educate an army of graduates destined for labour unemployment offices. Graduate unemployment some study programs, the unemployment rate to $14 \%$, [1]. Secondly-this poor use of finances is compounded when the Ministry of Labour and Social Affairs is given resources to support the unemployed, including unemployed graduates. Thirdly-this is further compounded when money is subsequently provided for retraining these unemployed graduates.

Given this threefold allocation of financial resources to young people's education and training, it is imperative to assess the effectiveness of the educational provision and to identify where the weaknesses lie. We propose to address three areas which we believe are central to this analysis: in the first place, we need to examine how effective the programmes of education are; secondly we have to scrutinise the quality and appropriateness of graduates; and thirdly we need to examine the links between the educational system and the needs of enterprises in terms of future employees. In this paper we confine ourselves to the area of mechanical engineering since this is the area in which we work and have extensive experience.

We believe that it is necessary however to undertake a similar critical and rigorous scrutiny of all other disciplines in order to provide guidance to policymakers on a more effective allocation of resources, and to offer examples of best practice to the educational establishment on ensuring that their curricula remain relevant to the needs of society.

\section{Underlying Problems Facing Technical Education in the Slovak Republic}

\subsection{Demographics-Falling Student Numbers}

Currently the number of technicaly universities leavers is falling because the number of students in secondary schools is falling. Statistics show that number of graduates of secondary schools decreased in Slovakia in 2010-2014 approximately about $17 \%$, [1].

Furthermore the quality of education in technical subjects such as maths and physics in secondary schools is inadequate. Mathematics and physics graduated only about $16 \%$ graduates, [1].

To compound these difficulties, student motivation for studying at technical universities is low, [2]. This is due largely to the fact that technical education in our society is undervalued, something which is beyond the scope of universities alone to correct.

However, there are measures that can be taken to encourage a greater uptake of technical education, not least through a system of financial support for students, which we examine later in this paper. 


\subsection{Access to University Study - Open Door, or Open Access?}

Currently, more than $60 \%$ of school leavers want to study at university, [1]. On the other hand, more than $50 \%$ of students in their first year of undergraduate study find the courses too difficult and fail to complete them, [3].

Even if they appear to be unlikely to complete their studies, there is a tendency for the university to accept them because its funding, and therefore its existence, depends on the numbers of students it has.

\subsection{Appropriateness of First and Second Degree Studies}

A second significant problem is that those graduates who do succeed in completing their first degree lack adequate practical experience (praxis) to enable them to be easily integrated into the world of work. Lot of employers argue that graduates have lack of experience, [3,4].

Furthermore, the curriculum at first degree and second degree level is often very similar in the SR., At the same time, more than $90 \%$ of first degree students continue to the second degree level. The difficulty here is that the first degree is not adequate either as preparation for

\section{HOW IT WORKS......}

employment (general training) or for research. After completing their first degree, when students are unable to find employment, so there is a tendency for the university to allow them to continue out of consideration of financial self-interest, [1].

\section{Tackling / Resolving the Problems}

\subsection{Revising the Graduate Pathways}

The educational provision offered by universities, and the knowledge and practical skills demanded by businesses are often very different and contradictory. Current bachelor degree graduates have insufficient experience. Moreover, even if they decide to seek work in a company after gaining their first degree, they are practically unemployable from the perspective of the needs of the companies.

One possible solution to this problem is the education and training of professional bachelor degree graduates who would be more adequately prepared for practical work on completion of their first degree. An example of this approach, from carmaker PSA Peugeot Citroen, is presented in Figure 1. But this four-year system, now we don't have accredited.

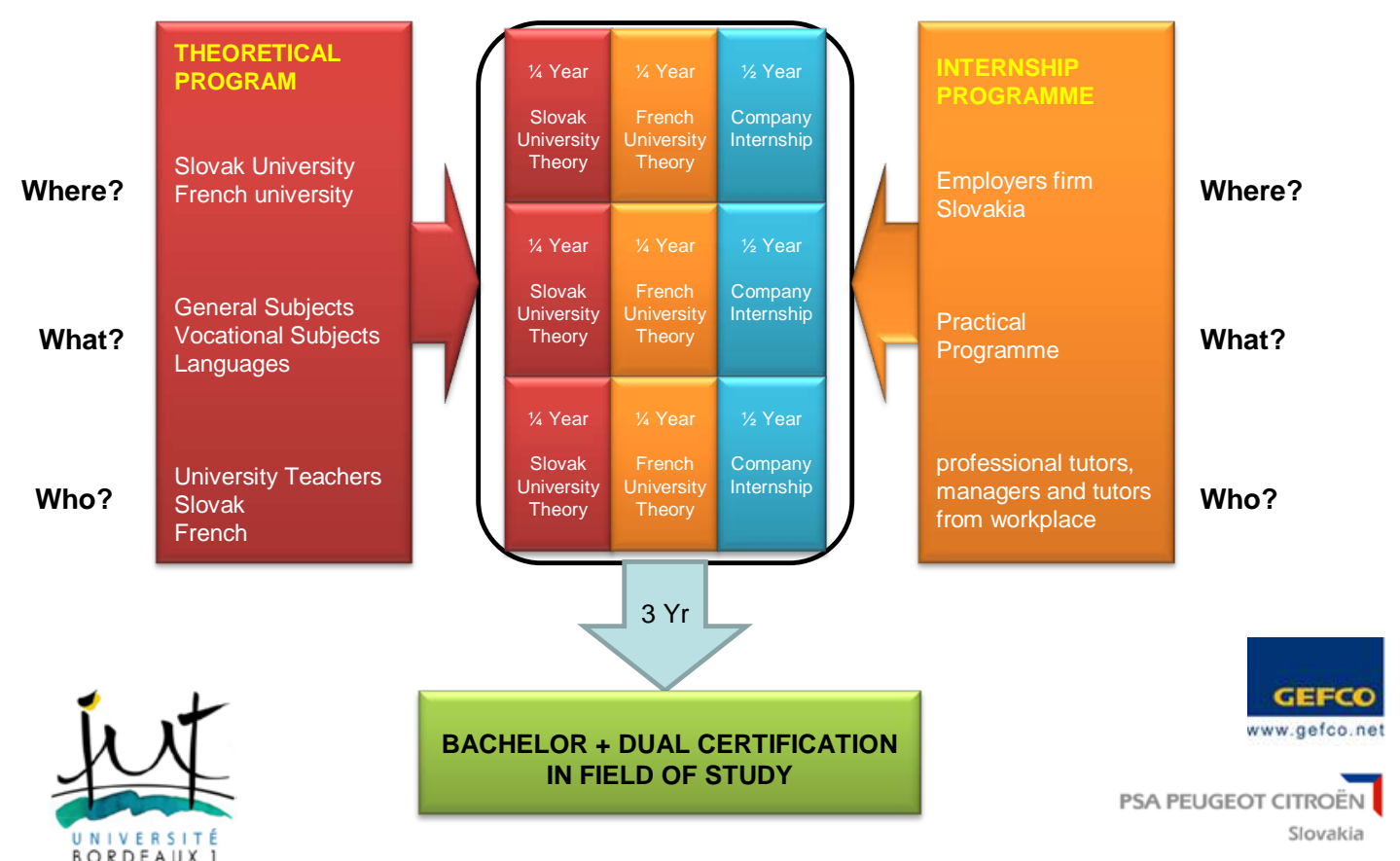

Figure 1. How the Three Year Dual (France and SK) Certification Accreditation Proposal Would Work, [3]

If we accept the needs of industry, the solution would be to extend the length of bachelor degree study to four years. In this model at the end of the second year students have to pass a rigorous exam in order to be able to continue the traditional pathway to completing their first degree, with the possibility of subsequently studying for their second degree. Those students who are unlikely to be successful on a master's study programme would be directed towards the "Professional four-year Bachelor degree." Thus, they would graduate with experience of the 'world of work' and having had the opportunity to develop the 'soft skills' during this experience that employers value so highly.

Unfortunately under the current education system, such a proposal would not be acceptable because it does not meet the requirements of the educational process, [3].

Teaching the third stage of an undergraduate degree under this proposal would be extended over two years, with one semester of each year being an internship. Such a proposal would make it possible to prepare graduates with 
the necessary experience. Equally it would offer the best option, since, after passing the "four-year professional bachelor degree", students can still proceed to the second,
Master degree programme because they will have fulfilled the requirements in terms of the content and scope of the teaching programme.
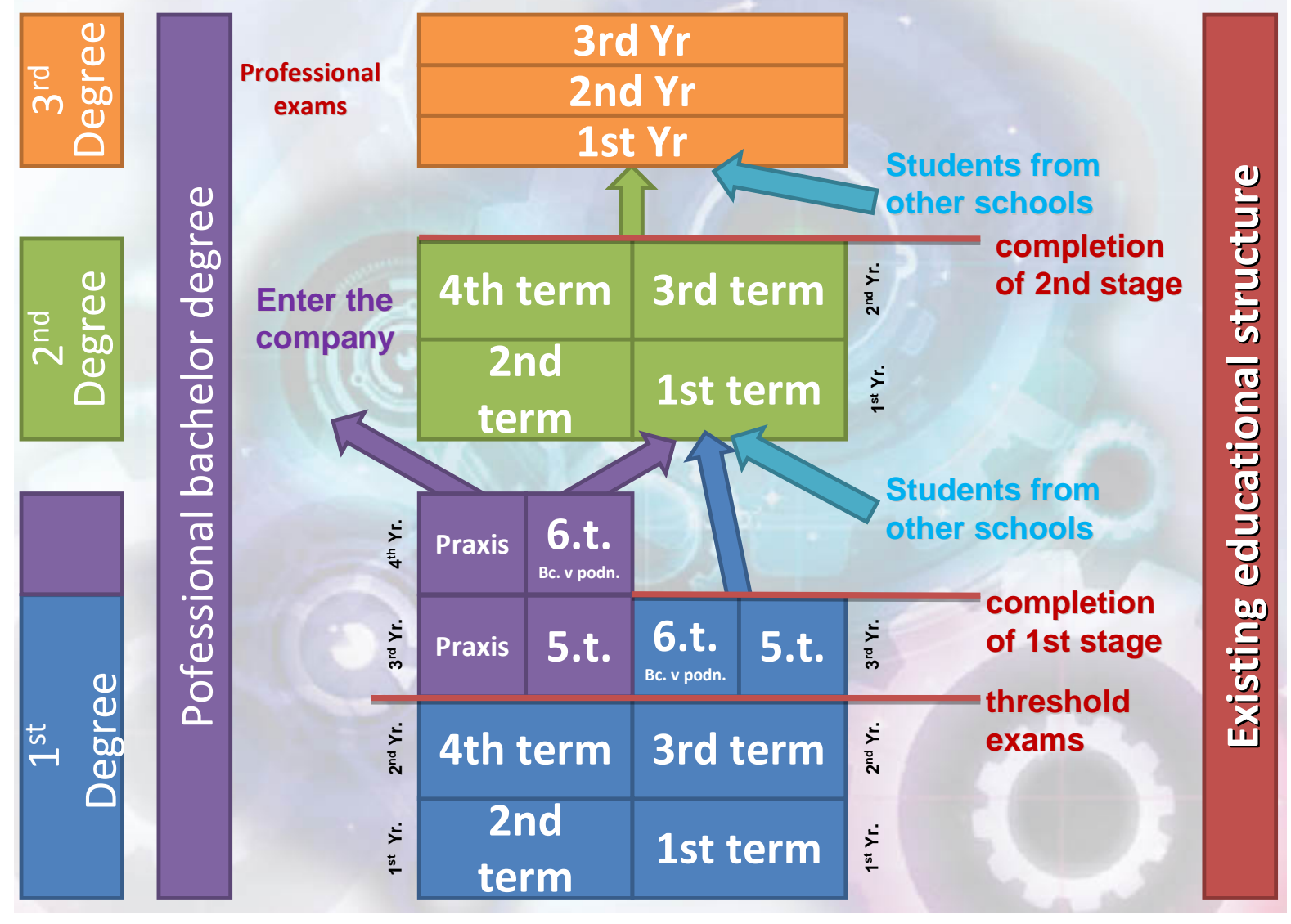

Figure 2. Schema of Professional 4 year Bachelor Degree

\subsection{Changing the System of University Financing}

The system of financing universities in Slovakia has remained unchanged for several years. Financial support is based on the results of scientific research undertaken, the level of success in winning grants, publications, the number of international students, and the overall number of students attending the institution. Regrettably, the most important of these criteria is the number of students on courses. If the institution has enough students it will be financially secure, irrespective of the success or otherwise of its graduates obtaining work in positions related to their studies. On the other hand if a high quality university, gaining excellent results in scientific research, and with highly demanding study programmes does not have enough students, it faces problems of financial survival.

Many school leavers, when choosing their future university courses, select the option of 'least resistance', meaning that perversely, it is the institutions that offer the least demanding and lowest quality educational courses which thrive financially, whilst those institutions which offer more challenging studies and produce graduates of a higher calibre but in smaller numbers are at risk.

The corollary of this practice is that it is the latter institutions that frequently excel in terms of preparing their graduates for study related employment through their attention to ensuring the relevance of their courses to the changing societal needs, and to the skills development of their students through carefully structured work placements. It is usually these institutions which achieve the highest levels of study related graduate employment, [4] offering further evidence of the advisability of using the relevant employability outcome as at least one of the criteria for assessing teaching success.

A similar problem at Secondary level, was identified by a 2012 OECD report which stated that: "The allocation of funds in the education system could be improved as it is not sufficiently orientated towards quality improvement. ..... The funding of schools is mainly determined by the number of pupils and the amount of funds allocated per pupils does not depend on outcomerelated criteria”, [5].

Taken to its extreme, and with slight exaggeration, this system of financing education could lead to a scenario in which a school or university educates and produces a Nobel prize winner, but may well close as he/she is just one graduate and the system values quantity over quality.

The proposal for a complex accreditation process put forward 5 years ago was interesting. Universities were to be divided into 3 groups - universities, high schools, and specialised high schools, each rated according to the results of their accreditation. These 3 groups were to receive different amounts of finance, with up to $70 \%$ difference between those with the highest and those with the lowest accreditation rating. Unfortunately, this system did not get the support of the politicians, and was not implemented.

Problems also exist with the financing of different types of university. State universities (those offering tertiary education to the police, armed forces etc.) receive funding 
per capita of student, directly from the state. Public universities (those offering tertiary education to all - by far the largest number) can decide either to receive funding per capita directly from the state, or to charge student fees. Private universities enjoy the most favourable conditions because they are able to receive funding per capita from the state as well as charging their students. A similar financing problem exists amongst different types of university. No account is taken of the different resource requirements needed to teach economics, philosophy, pedagogy or theology, for instance, compared to the those needed to educate students in technical subjects, pure sciences, medicine, or agronomy,

If the state really wants to make the financing of universities more effective, it needs to adopt the criterion of financing according to the employment successes of its graduates, instead of allocating resources according to the number of students taught. This more comprehensive approach would also take into account the number of companies interested in graduates from specific university faculties, how many graduates actually find work related to their area of study, and the average salary gained by those graduates. This latter point would be a good indication of relevance of the courses studied with regard to employment in the private sector, but not necessarily to the public sector.

In the past a 'National Classification of Professions' was established, and in the near future the National Classification of Qualifications` should be completed. When completed it will be possible to connect the two, and the state will be able to identify which qualifications are most needed by industry and society. The state can then plan the provision of qualifications offered by the universities. The state has the tools (preferential financial treatment, provision of student loans etc.) to give preference to those state funded programmes which are in greatest demand.

\subsection{Improving Study Motivation}

Study related bridging loans could be a very useful tool in this endeavour. The motivating stipend currently available to Slovak students does not guarantee that the graduate will work in the area they studied after completing their studies, because there is no requirement to repay the money. A more effective way to motivate the student would be through a system of bridging loans. This system is beneficial, especially for students from socially deprived families, [5] as students would be eligible to receive a loan for their study and, after completing their studies, would repay the loan. How much, and over what period of time, would be calculated according to the nature of the student's subsequent employment. If employed in their specialised study area over the same number of years as the years of their study, the loan would be written off. If the student graduate does not work in his/her specialised study area at all, or for only a short time, he/she would have to repay the stipend in its entirety, in the case where they do not use their training at all, or a percentage of the stipend, reduced for each year of relevant employment. To implement the system it would be necessary to monitor graduate employment by connecting a graduate portal with the social security database.

\section{Matching Students with Enterprises during their Study}

Clearly then, there is an urgent need to reinforce the links between universities and enterprises to ensure that the money dedicated to educating our young people is targeted to educate them for employment rather than unemployment or what we can term "mis-employment". The latter represents a tragic waste of funds, and when taken with the over-provision of tertiary educational establishments (37 in a population of just $5 \mathrm{~m}$ ) can only be seen as an unjustifiable waste.

\section{Looking towards the Future: Two Examples of "Best Practice"}

Finally we present two interesting projects which may offer examples of 'best practice' in confronting the problems of ensuring the relevance of student education and training. They are: Universities - Engines of the Knowledge Society (hereinafter MVS); and the Postgraduate Research Centre project (PRC).

The first of these projects, MVS, is designed to enhance the relevance and quality of short and long term student internships in companies. The aim is to identify those university study programmes which are in greatest demand by businesses enterprises, in order to be able to provide students not only with relevant theoretical knowledge, but also with the practical experience through direct contact with the advanced technologies being used in practice in the most dynamic sectors of the employment market.

The project falls under the auspices of the European Union, European Social Fund-Operational Programme, Education, and has a budget of $€ 17.072$ million. The project covers the entire territory of Slovakia with the exception of the Bratislava region. The duration of the project is 31 months, from May 2013 to November 2015. As of autumn 2014, the first stage, ranking the cooperation between universities and enterprises has been completed, having identified 2,686 examples of "best practice". These examples were ranked according to the degree to which they met the criteria set out by the expert group composed of representatives of universities and companies. On the basis of this survey a list of the one hundred, most sought after study programmes will be created. Industrial associations will identify the most attractive programmes in their economic sectors, Figure 3, [6]. Within their own particular sector, trades unions in the A5 Association's group (ZSP - Mechanical Engineering; ZAP - Automobile Engineering; EPZ - Electrical Engineering; ZSI - Civil Engineering; ZHP Metallurgical Engineering) will prepare long-term internships for students on the basis of contractual relations with the sector members. Fifty students will be catered for in each of the associations. The students will spend three terms undertaking a total of 96 hours per term in the companies, [Figure 3.] More information on the project, as well as on the offers of businesses and work areas in which companies offer the best collaboration is available on the website www.vysokoskolacidopraxe.sk. 


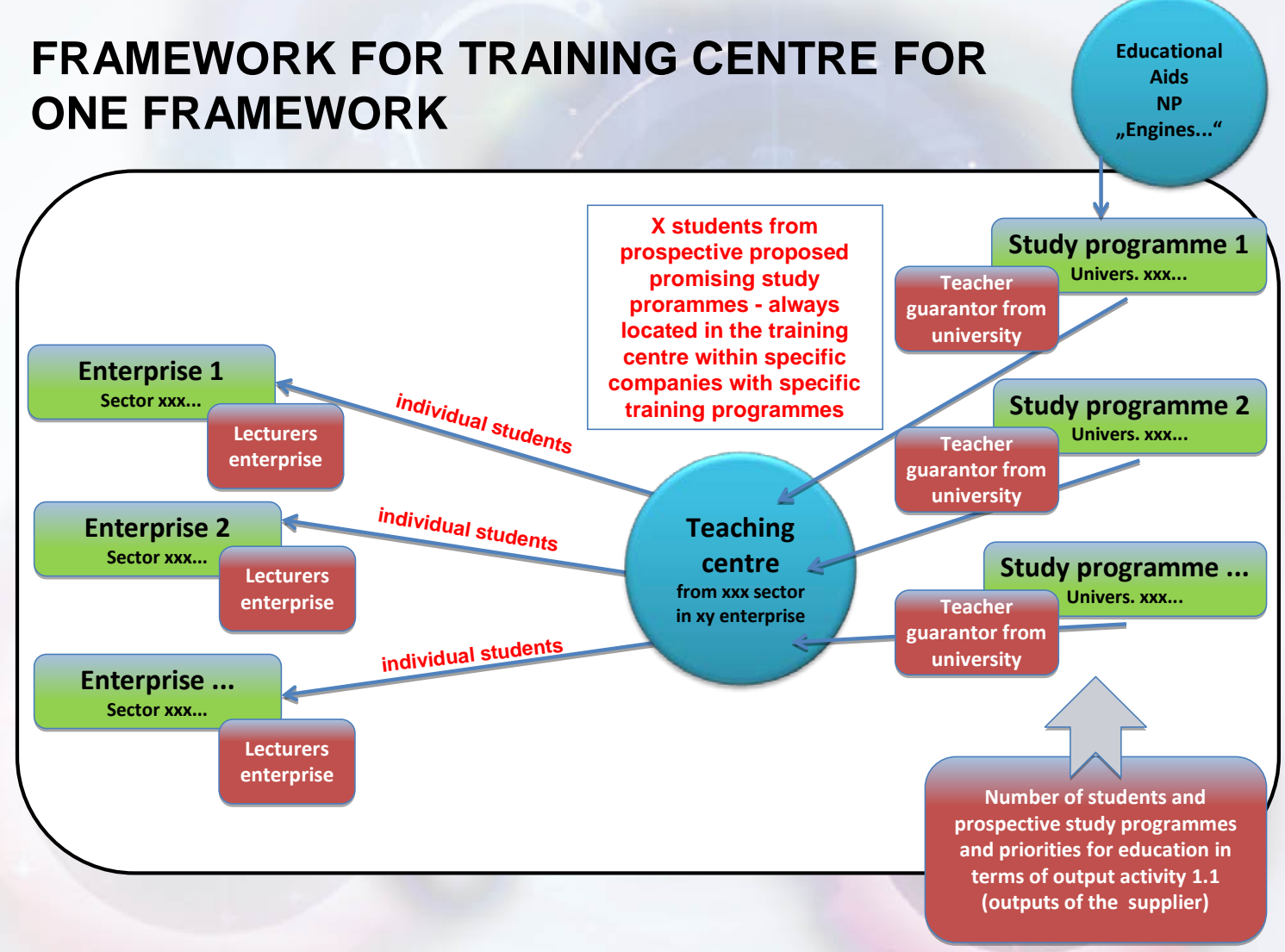

Figure 3. Basic scheme of the training centre, [6]

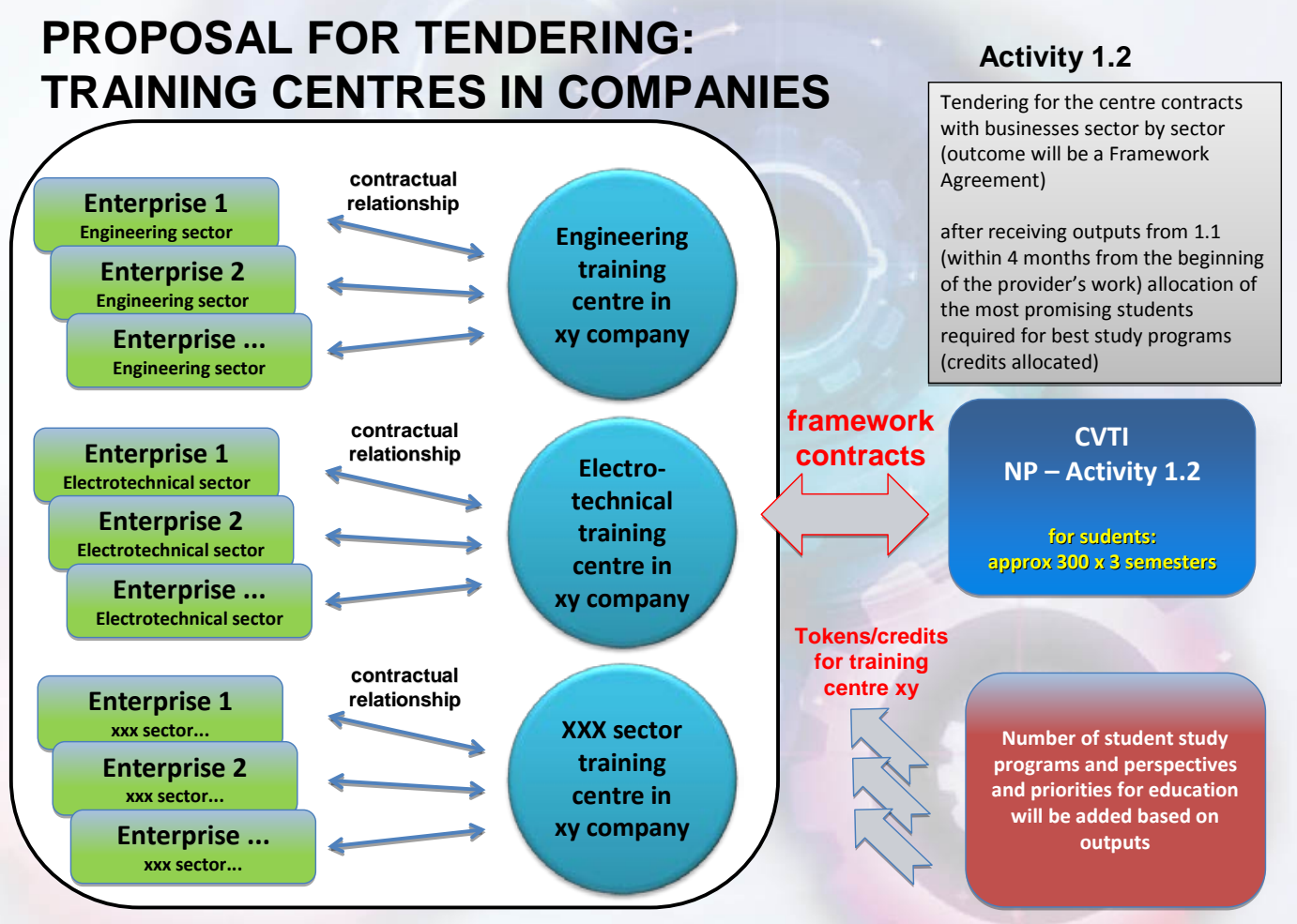

Figure 4. Contractual arrangement for individual training centres, [6]

\subsection{The Postgraduate Research Centre}

The second project designed for second degree (Eng.) graduates and third degree (PhD.) graduates, aims to provide the necessary practice and research skills for graduates. On the basis of actual requirements of enterprises, graduates will work on specific projects is under the guidance of experienced supervisors, [7]. The project is coordinated by the Federation of Mechanical Engineering Industry and began in March 2013. The 
project covers the whole territory of the Slovak Republic. The project will be funded partly by the Ministry of Employment Social Affairs and the Family, and partly by the enterprises themselves. The basic premise is that the selected graduates are undertaking project development as employees of a particular company. After the agreed period, or alternatively after completion of the research project they will return from the Research Centre to the same enterprise.

Students spend part of their working time during the project in the PRC under the guidance of experienced supervisors, and part of the time in the company under the guidance of experienced practitioners. The wages of the graduates is made up of a contribution from the Ministry of Employment, Social Affairs and the Family, together with a contribution from the particular enterprise involved, Figure 4. After completing an internship in the PRC the graduate-employee, having acquired knowledge and experience in the field required by that particular firm, has a good understanding of a well-designed project, and of the company for whom the project was designed. The company benefits from a fully or partially completed project available for series production, and at the same time gains an employee with the required knowledge and practical experience. The results of a recent survey sent out to engineering companies indicate that over the next 35 years they will need 560 graduates with well-defined requirements in terms of their knowledge, technical and language skills, or possibly with a project they intend to develop.

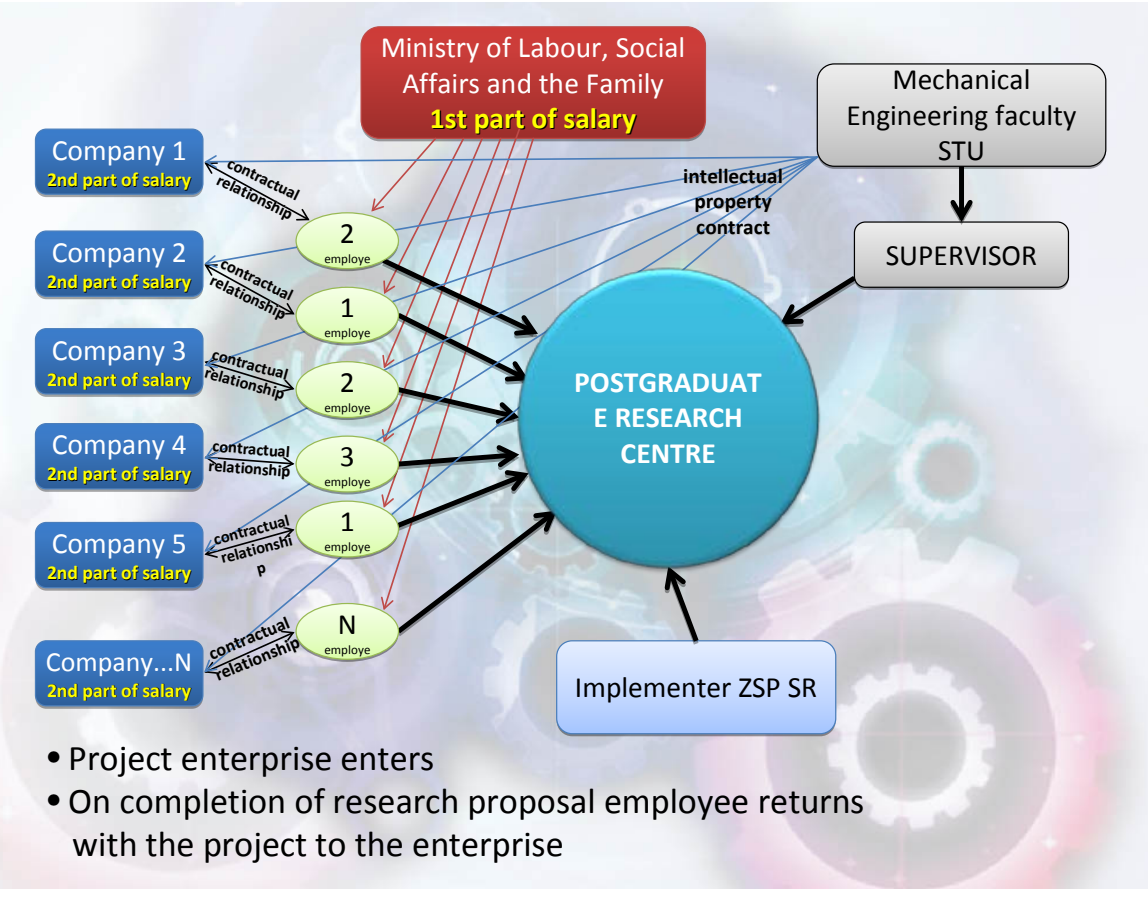

Figure 5. Diagram of postgraduate research centre, [7]

\section{POSTGRADUÁLNE VÝSKUMNÉ CENTRUM}

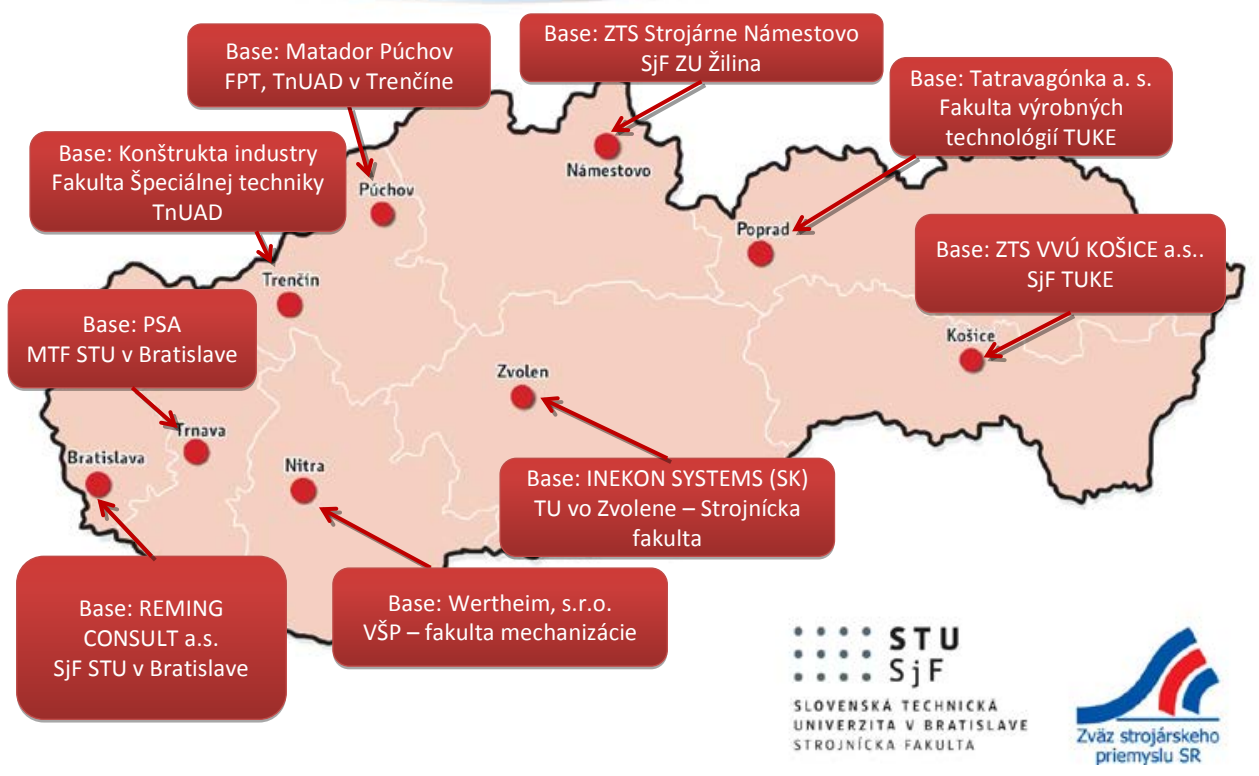

Figure 6. The planned network of postgraduate research centres, [7]. 
The project envisages the creation of nine such research centres in Slovakia, where the link will always be between companies located in the catchment region of the local university. The PRC will provide the channels for bringing together young scientists and enterprises according to the specific requirements of a particular geographical region, [Figure 5.]
By linking the two projects the advantage gained is that while the first project (university-MVS) aims at identifying intelligent and talented students for the needs of the enterprise, the second project (PRC) aims to respond to the needs of different geographical areas.

\section{POTENTIAL LINKS WITH THE POSTGRADUATE RESEARCH CENTRE}

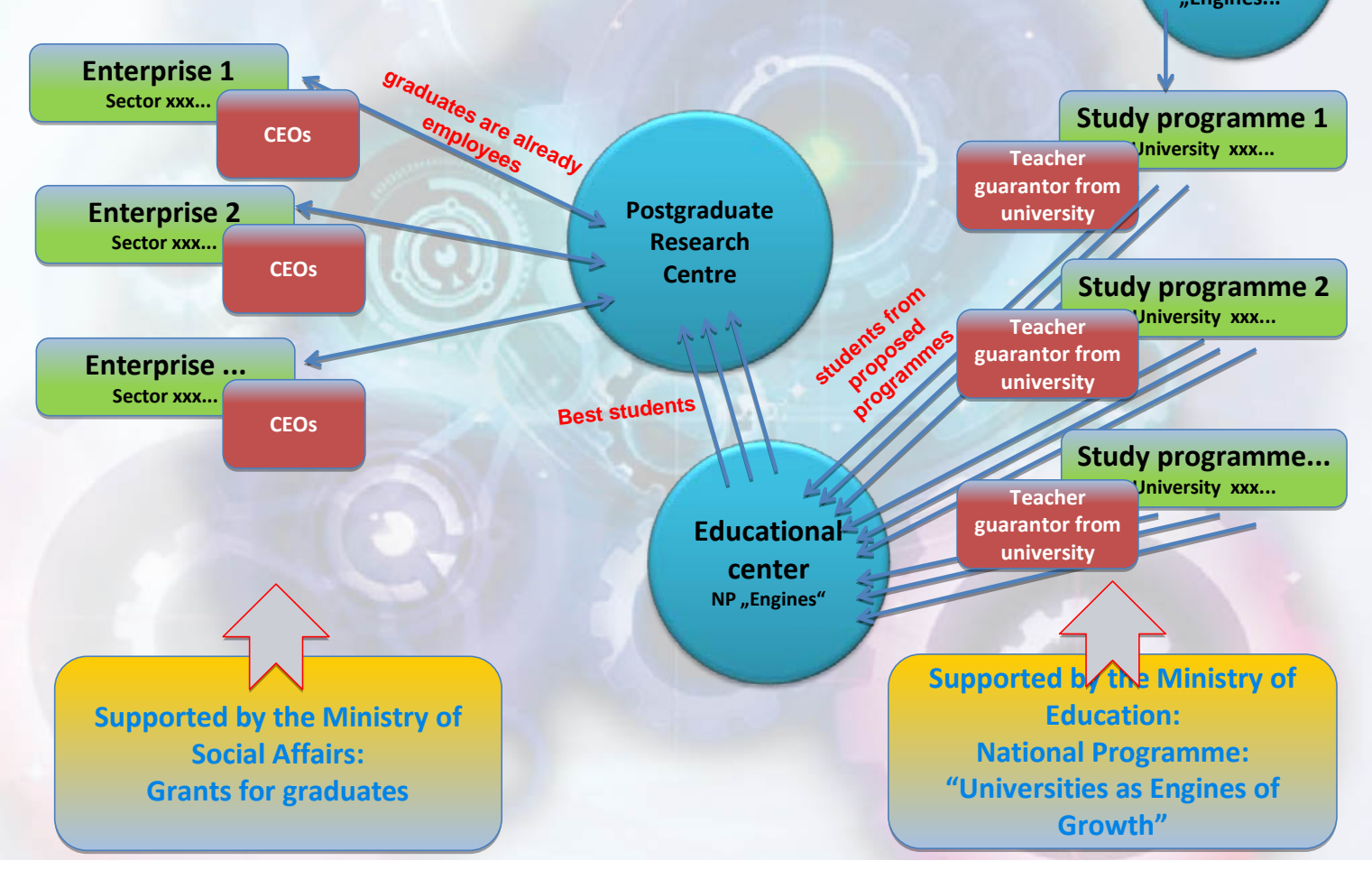

Figure 7. Benefits of interconnection of MVS and PRC projects, [7].

\subsection{Further Benefits of the two Projects include the Following}

For the University-MVS:

- Students are selected from the prospective study programmes

- During long-term internships, the company can identify the best students

- Validation / verification of competence, potential and motivation

- Targeted development of the competencies in demand

- Recognition of the company

- The possibility of elaborating the final project work in the company

- The financial costs of teachers and classroom and laboratory equipment is covered

- Strengthening cooperation with universities, including provision of equipment

For the PRC:

- Selecting the most promising, talented and motivated graduates

- Securing employment for graduates
- Continue working for the company-research role, greater added innovation

- Accelerated adaptation and performance on the basis of previous experience and development

- Further development of competencies

- Part of the cost of subsidies covered by Ministry of Labour Social Affairs and the Family

\section{Conclusion}

The aim of the present paper is to identify some of the most significant problems of Slovak higher education in the view of the authors, and to suggest at least some partial measures to improve the situation.

Slovakia is a technologically developed country. It therefore needs a significant number of technically educated graduates. Currently there are an insufficient number of university graduates at all levels to meet the needs of industrial enterprises. Furthermore, the content of the educational system fails to match the needs of enterprises. Students do not have adequate theoretical training in scientific disciplines, and lack work-place experience. 
The aim of this paper has been to objectively evaluate the educational opportunities provided by Slovak universities and the real needs of enterprises located within the country. We have offered two projects that suggest a solution if only in part to this problem, in an attempt to point the way to a more effectively functioning system in the future.

\section{References}

[1] HERICH, J.: Uplatnenie absolventov stredných škôl v praxi. Ústav informácií a prognóz školstva Bratislava, 2013. $46 \mathrm{~s}$.

[2] ŠOOŠ, L: Vizitka kvalitnej školy. In: Pro-Energy magazín. -Č. 3/2013 (2013), s. 16-18.
[3] ŠOOŠ, L'.-BROKEŠ, P.: Teaching paradigm of project/internship course units. In: Project work and internship: theory and practice. Wroclaw, Pol'sko, 6.-7.9. 2012.-[S.l.]: International center for entrepeneurship, 2013. 80-93.

[4] SCHWEIZER, D.: Vysokoškoláci do praxe-predstava PSA. Prezentácia v PSA dňa 17. 3. 2014.

[5] 'Education at a Glance' 2012, OECD indicators. ECD Publishing. Revised version, september 2012, $570 \mathrm{p}$.

[6] http://www.vysokoskolacidopraxe.sk/.: Vysoké školy ako motory rozvoja vedomostnej spoločnosti, 17,072 mil. EUR, ITMS 26110230120 v rámci operačného programu Vzdelávanie a jeho časti Reforma system vzdelávania a odbornej prípravy.

[7] ŠOOŠ, L: Applied research-the best bridge between school and industry through post graduate research centre. In: Procedia-Social and Behavioral Sciences. -Vol. 106: 4th international conference on New Horizons in Education. Rome /Italy/, June 25-27, 2013 (2013).-[S.l.]: Elsevier, p. 467-475. 